\title{
The Use of ICT in Education: Focus on Nigeria
}

\author{
${ }^{*}$ N. D. Oye ${ }^{1}$, N. A. Iahad ${ }^{1}$, M. A. Shakil${ }^{2}$ \\ 1Universiti Teknologi Malaysia, Malaysia \\ ${ }^{2}$ COMSATS Institute of Information Technology, Attock, Pakistan \\ *oyenath@yahoo.co.uk
}

\begin{abstract}
The use of ICT in educational settings is a catalyst for change. The paper has sought to explore the role of ICT in education as we progress into the $21^{\text {st }}$ century. The first phase focuses on the conceptual framework of the use of ICT in education. In this model the dependent variable is education and its sub variables are educational level of teachers and students which is directly affected by the independent variables which are the use of ICTs, ICT infrastructure and staff development. The second phase is the pilot study to answer two major questions: (i) Is ICT mandatory or voluntary at your institutions? (ii) What are the greatest barriers to using ICT to you as an academician? The results show that majority of the academic staff (86\%) responded that ICT is mandatory. However, the survey revealed that most of the part-time lecturers ticked the use of ICT as voluntary. Some of these part-time lecturers in the cadre of professors, responded to Q32 as (do not fit my program). Actually in their dispensation, lecturing was done using the chalk board only. The research confirms that two major barriers affect the use of ICT; they are lack of time to use ICT the systems and training opportunities. Respondents on these are 38\% and 32\% respectively. Based on these findings, the paper recommended that, all employed teachers in Federal, State and Private institutions should undertake mandatory training and retraining on ICT programmers. The government should develop ICT policies and guidelines for the application of ICT in education.
\end{abstract}

Key Words: ICT; Education; ICT infrastructure; Staff development; ICT tools

\section{Introduction}

Information and communication technologies (ICT) have become commonplace entities in all aspect of life. Across the pass twenty years the use of ICTs has fundamentally change the practice and procedures of nearly all forms of endeavor within business and governance. But with the world moving rapidly into digital media and information, the role of ICTs in education is becoming more and more important and this importance will continue to grow and develop in the $21^{\text {st }}$ century. In our society information and communication technology (ICT) places an important role. It is impossible to imagine life today without computers. Government of most country has understood this development and has realized the influence of ICTs on the economy. Various departments have drawn up policy document with regard to ICTs.

Research into information and communication technologies (ICT) in organizations is well into its third decade but there is still a pressing need to better understanding of how computer-based technology are influencing in learning opportunities, and how the local conditions of schooling impact on teachers' attempts to integrate this technologies in their classrooms. It seems that organizations are very much aware of the relevance of these issues. The implementation of the use of ICTs in education was and is essential to address the issues of how ICTs is used as object of learning (to acquire ICTs related skills) and as a tool for realizing particular educational objectives, especially the ones that are believed to be associated with the learning society, efficiency, competitiveness, effective learning, print content delivery, and distance education. The basic aim is to provide concrete results about the use of ICTs in education.

\section{ICT in Education}

The term, information and communication technologies (ICT), refers to forms of technology that are used to transmit, store, create, share or exchange information. This broad definition of ICT includes such technologies as: radio, television, video, DVD, telephone (both fixed line and mobile phones), satellite systems, computer and network hardware and software; as well as the equipment and services associated with these 
technologies, such as videoconferencing and electronic mail. ICT in education means teaching and learning with ICT. Researches globally have proved that ICT can lead to improve students' learning and better teaching methods. A report made by the National Institute of Multimedia Education in Japan, proved that an increase in student exposure to educational ICT through curriculum integration has a significant and positive impact on student achievement, especially in terms of "Knowledge Comprehension" . "Practical skill" and "Presentation skill" in subject areas such as mathematics, science, and social study.

While we recognize that the use of instructional technology in the higher education teaching and learning processes is still in its infancy in Nigeria, ICT instructional use is vital to the progress and development of faculty and students alike. Higher education institutions, especially those in the West, have adopted ICT as a means to impart upon students the knowledge and skills demanded by 21st century educational advancement (UNESCO, 2009). ICT also adds value to the processes of learning and to the organization and management of learning institutions. Although some HEIs have the zeal to establish effective ICT education programmers, they are faced with the great problems of proper implementation of the programmers. The most important of these is poor ICT penetration and usage among Nigerian higher education practitioners. Almost all African countries' basic ICT infrastructures are inadequate; a result of a lack of electricity to power the ICT materials and poor telecommunication facilities. Above all, this lack of access to infrastructure is the result of insufficient funds (Ololube \& Egbezor, 2009).

Many cities and rural areas in Nigeria still have fluctuation in their supply of electricity which makes the implementation of ICT in education most difficult. Furthermore most Nigerian universities do not have access to basic instructional technology facilities, which also make the integration of instructional technology in the delivery of quality education difficult. Therefore, computer related telecommunication facilities might not be very useful for most Nigerian students and faculty members, as computers are still very much a luxury in institutions, offices and homes. This has made the integration of essential on-line resources (e-mail, worldwide-web, etc.) into higher education most difficult. In higher education, an important aspect of the shift in technological processes has been to the acceptance and use of ICT for teaching and learning((Oye, Iahad, \& Ab.Rahim, 2011). According to the Commonwealth of Learning International (2001)," another serious challenge facing higher education in Nigeria is the need for integration of new ICT literacy knowledge into academic courses and programs. In this regard, professionals in Nigeria have not been able to benefit from international assistance, international networking and cooperation, or from courses, conferences and seminars abroad, because of lack of funding."

Educational ICT Tools: Educational ICT tools can be grouped into three sections thus: Input source, Output source and others

ICT proficiency is the ability to use digital technology, communication tools, and networks appropriately to solve information problems in order to function in an information society. This includes the ability to use technology as a tool to research, organize, evaluate, and communicate information. ICTs have the potential for increasing access to and improving the relevance and quality of education. The benefits of ICT tools for education are that, through ICT, images can be used in teaching and improving the retentive memory of students. Through ICT, teachers can easily explain complex instructions and ensure students' comprehension. And through ICT, teachers are able to create interactive classes and make the lessons more enjoyable. Although ICT in education also have some disadvantages such as complications in setting up the device, too expensive to afford and hard for an inexperience teachers to use, this cannot be compared to its great advantages it has for teaching and learning. 
Figure 1: ICT in Education
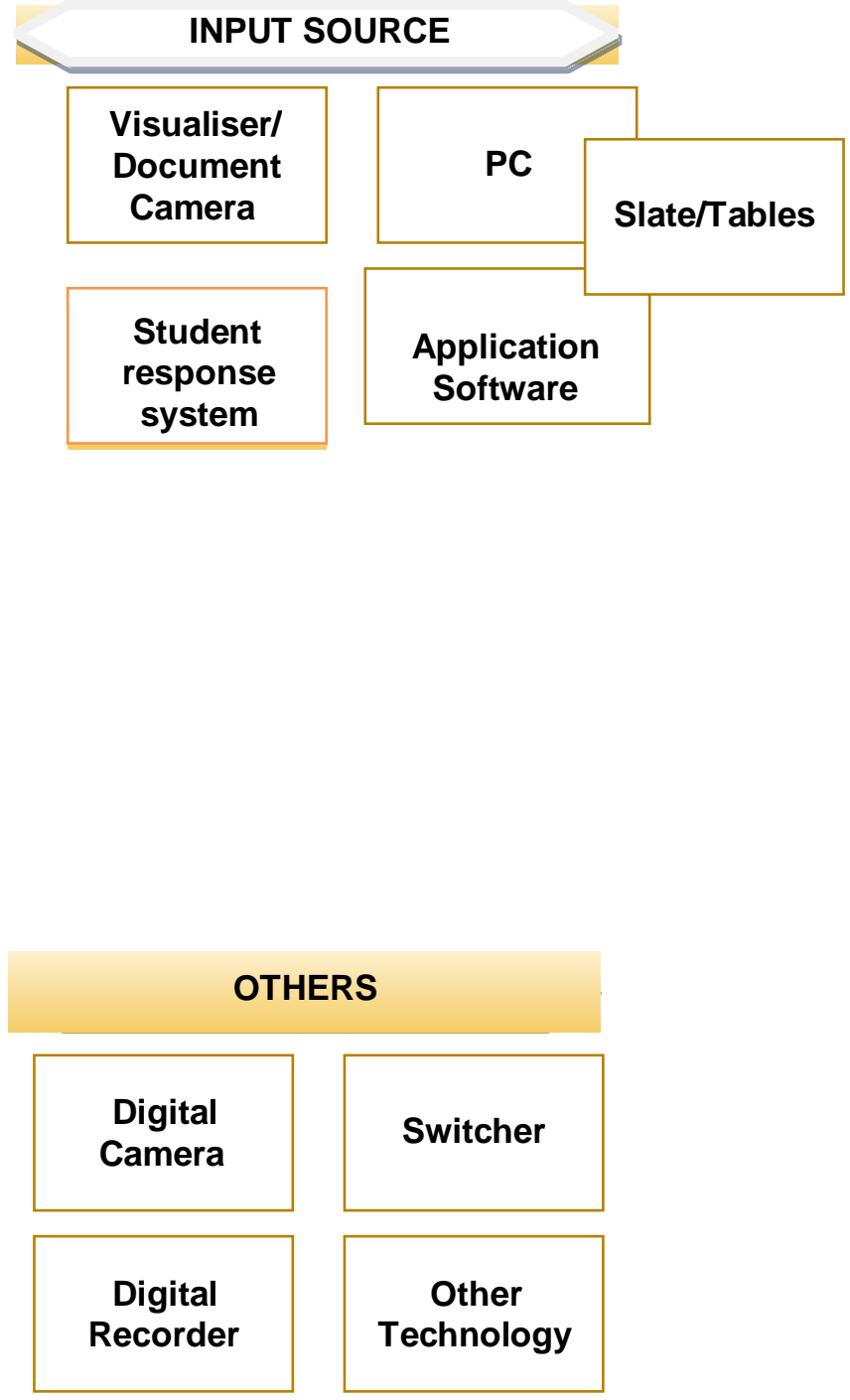

Fig 2: Pictorial Illustration on the use of ICT in Education

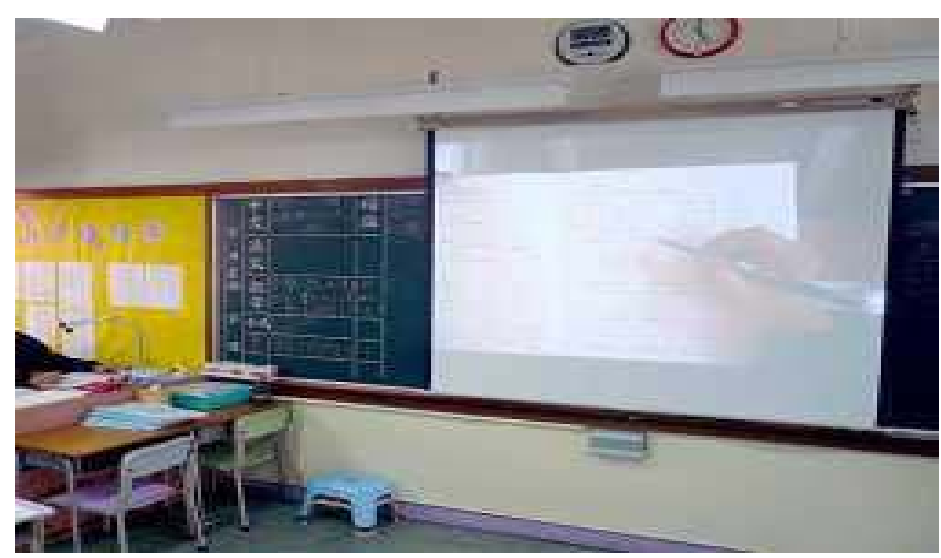




\section{Use of multimedia projector in the classroom to enhance teaching and learning}

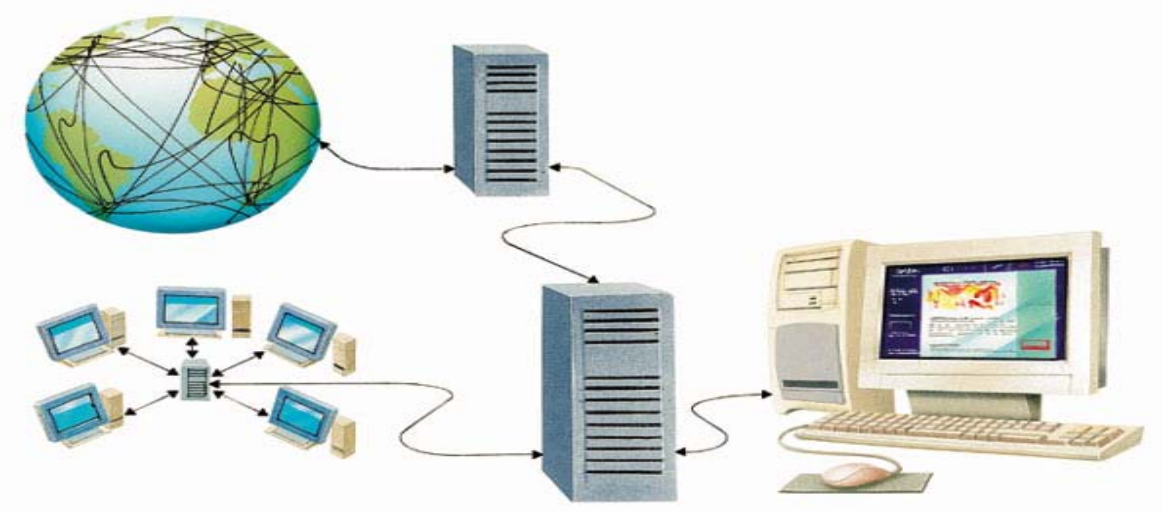

The internet allows for resource sharing and knowledge up-date

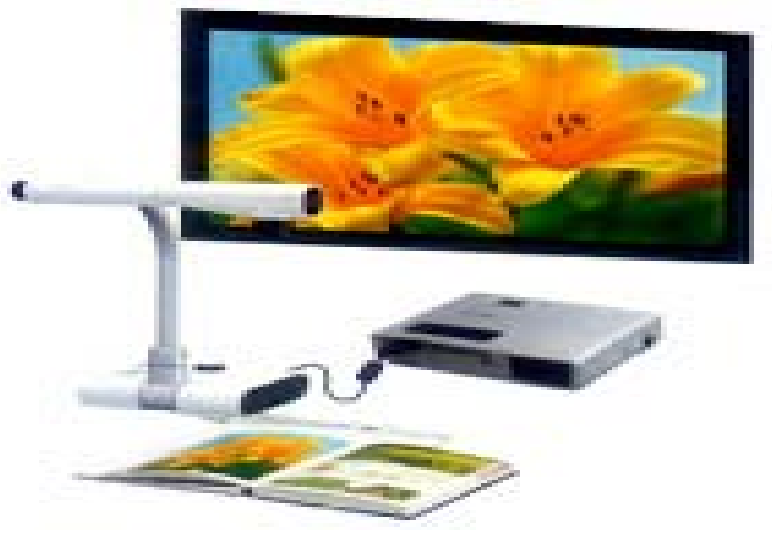

The Visualize/Document Camera: The benefit acquired from the use of ICT in education cannot be over emphasized as we live in an information age. Even with the conditions and huddles that surround ICT in education, optimism for the realization of Nigerian ICT and higher education goals remain; especially following China's launch of a communication satellite for Nigeria. This is the first for an African country and the first time China has provided both the satellite and the launch service. The Nigerian Communication Satellite (NIGCOMSAT - 1) is a super hybrid, geostationary satellite that will provide communication services for Africa, and parts of the Middle East and Southern Europe. "Experts have predicted that the satellite will revolutionize telecommunications, create professional IT jobs and provide Internet access in remote villages. It is also expected to improve e-commerce and government efficiency by promoting the development of a digital economy in Nigeria and the rest of the African continent" (Ololube \& Egbezor, 2009).

Adoption of ICT in Education: In developing countries Nigeria precisely, preliminary investigations show that only a few organizations in the economy have adopted the IT, but there has not been formal study to determine the level of diffusion and the factors affecting IT diffusion as well as impact on the efficiency of the organizations. Achimugu, Oluwagbemi, Oluwaranti \& Afolabi (2009)opined that the adoption Information Technology (IT) successfully in Developing Countries is one of the most pressing current developmental issues. Since IT became commercial in the early 1990s, it has diffused rapidly in developed countries but generally slowly in developing ones. Nigerian universities are focusing on curricula that might contribute more directly to economic growth and network as in the case of Nigeria today, individuals may not use ICT service for different reasons ranging from lack of interest, illiteracy, lack of awareness, exorbitant rate of services, poor quality of service and low per capita income.

The United Nations have identified four major sets of indicators for complete information technology diffusion in a country (Chiemeke \& Longe, 2007): (a) ICT infrastructure and access. (b) Access to and use of ICT by households and individuals. (c) Use of ICT by businesses and (d) ICT sector and trade in ICT goods. The use of internet as a communication channel in Nigeria has led to increased productivity in sectors such as the educational, banking, communication and security, while Nigeria is gradually joining the league of globalizes 
nations.(Modupe \& Binuomote, 2007), examined the awareness and adoption of Information Communication Technology (ICT) among secretarial staffs of Ladoke Akintola University of Technology, Ogbomoso. It was discovered that the level of adoption of Information Communication Technology (ICT) among the staffs in still low, information will have to be processed in a daily bases. However, recognizing the key roles that secretarial staffs play in University administration, it was recommended based on the findings of the study that more computer facilities are provided for these staffs, coupled with a good access to internet facilities. Bridget (2008) opined that pedagogical adoption of ICT is complex and requires an integration of vision, system-wide experimentation and new roles and relationships for teachers and students. ICTs, when used in ways that make use of their affordances, are a powerful driver for change. Let us not forget that classrooms have never been ideal learning environments and teachers in public education systems have always been somewhat burdened by working with students who are there under compulsion. ICTs can help to make schools less-stressful workplaces for both teachers and students.

The rapid diffusion of the Internet has not only generated a renewed interest in the role of new information and communication technologies (ICTs) in higher education and learning (Dutton \& Loader, 2002), but it has also affected the ways people teach and learn(DeLacey \& Leonard, 2002; Radcliffe, 2002). At the same time, there has been growing concern over the possible decline of traditional practices and institutions, as elearning, virtual universities, and distance education become feasible alternative platforms for higher education. Students, teachers, and administrators have continued to employ the Internet and Web for their practices, and e-learning have remained a key item on educational agendas. The adoption of these systems in campus settings has many implications for ICT innovations in education. The internet is a major driver of ICT in education. Bandwidth is a major issue in the deployment of e-learning (Oye , Salleh, \& Iahad, 2010).

Theoretical Framework: Our focus of the research in the area of education is to find the relationship between the ICT and the education and the relationship of other sub variables. Here the dependent variable is the education, as education depends on the independent variable (ICT) usage in education.

Fig 3: Conceptual Framework

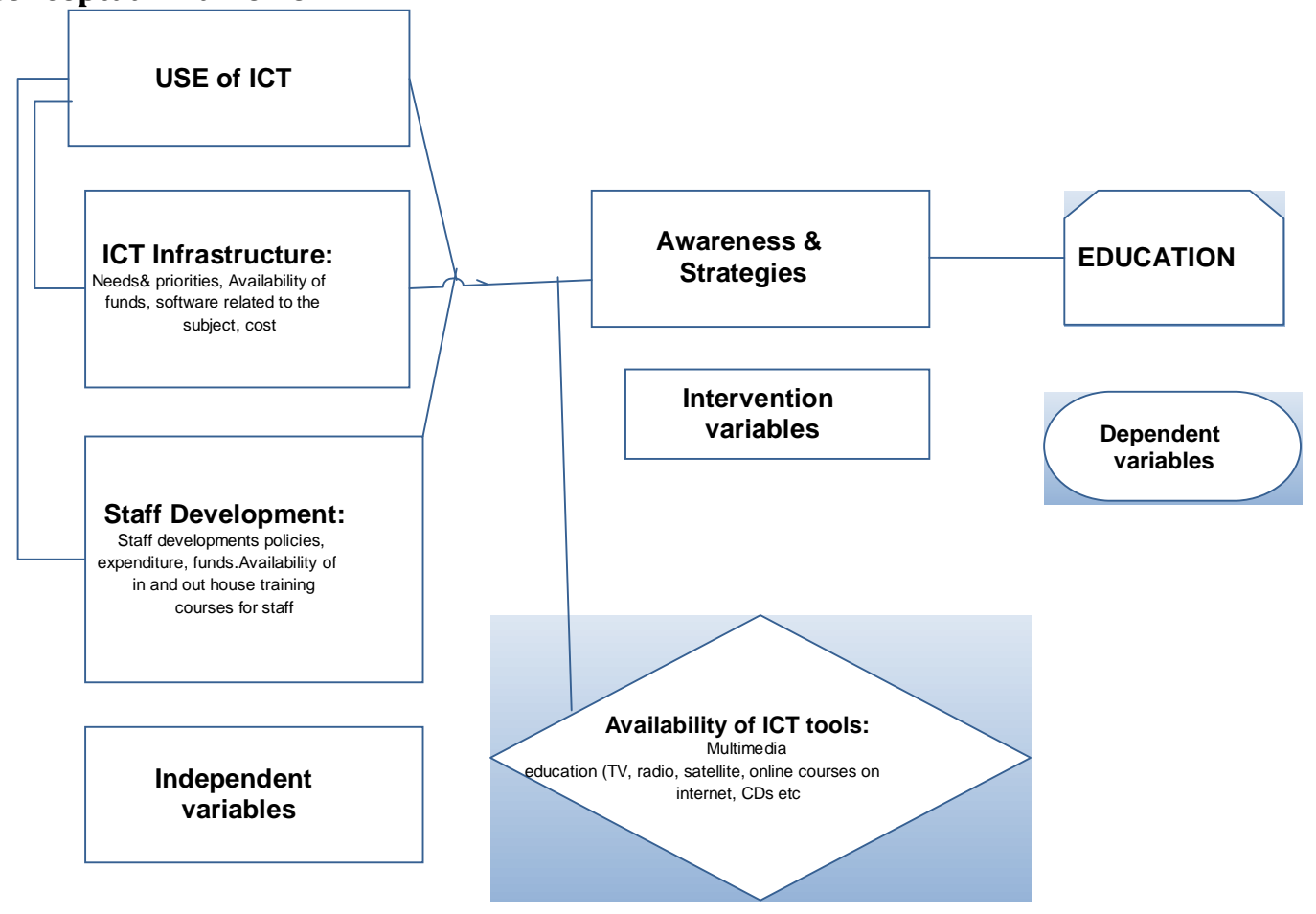

In this model the dependent variable is education and its sub variables are educational level of teachers and students which is directly affected by the independent variables which are the use of ICTs, ICT Infrastructure and staff development. ICTs infrastructure and staff development also have a strong relationship with the use 
of ICTs which is an independent variable, because the availability of the ICTs infrastructure and staff development will enhance the use of ICTs in education. The sub factors of ICTs infrastructure which are needs to develop the ICTs infrastructure. What are the priorities of developing this infrastructure whether to diminish the role of teachers from teaching process or to make the students independent in a sense that they can study without teachers depending on the availability of useful data. Availability of sufficient funds, cost of ICTs infrastructure, availability of software related to subjects are also the sub factors that influence the development of ICTs infrastructure.

The availability of ICTs tools consists of multimedia education like TV, Radio, Internet, Satellite, Online courses etc. These tools will ensure the development of ICTs infrastructure and will also ensure the use of ICTs in education. The student computer ratio is conceived indicators of the availability of the computers, average percentage of multimedia machines and other ICT tools etc. The second most important independent variable is the staff development and training regarding ICTs because training and development will make the staff capable to guide the students well about the use of ICTs and this will also enhances the education of students. The sub factors of staff development are the policies of organizations and institutes regarding training and development of staff, funding, expenditure on staff development, availability of in and out house training courses for staff influences directly the staff development and training from quantitative as well as qualitative studies. Finally there is an intervening variable that is awareness of ICTs which increases with the passage of time after seeing the ultimate progress in the field of education by using ICTs as a means of instruction.

Awareness campaign and sensitization of personnel is a necessary step in developing ICT infrastructure in education. Organization of seminars, conferences and workshops for top management and other critical staff within the Ministry of Education, National University Commission (NUC), and in the universities and with other stakeholders are necessary in ICT infrastructure development. These workshops, seminars and conferences aimed at raising the level of awareness of the infrastructure challenges, to discuss the users need and various infrastructure options, to promote and encourage multi-stakeholder approaches, to solicit feedback from management and staff (Gesci, 2007). The effective deployment of ICTs in education will therefore require that Ministries of Education collaborate with other ministries and government bodies responsible for infrastructure and ICT and associated policy development and planning. Ministries and NUC also need to establish close working relationships with the private sector and civil society involved in developing and promoting ICT policies, plans and infrastructure. Ministry of Education should hold meetings with other important ministries and stakeholders.

\section{Methodology}

The study use pilot questionnaire administered at the University of Jos in November, 2010. Parts of the demographic statements are considered to answer two major research questions:

(i) Is ICT mandatory or voluntary at your institution?

(ii) What are the greatest barriers to using ICT to you as an academician?

The descriptive survey design was used for this study. The pilot study contain two sections A and B. Section A is the UTAUT survey which contain 23 statements, while section B is the demographic information with 9 statements totaling 32 statements in all. This paper will concentrate on section B. Our statistical results are obtained using SPSS.

\section{Results and Discussion}

Table 1: ICT mandatory or voluntary at your institution

\begin{tabular}{llllll}
\hline & & & & Cumulative \\
& & Frequency & Percent & Valid Percent & Percent \\
\hline \multirow{3}{*}{ Valid } & MANDATORY & 89 & 89.0 & 89.0 & 89.0 \\
& VOLUNTARY & 11 & 11.0 & 11.0 & 100.0 \\
& Total & 100 & 100.0 & 100.0 & \\
\hline
\end{tabular}


Research Question (i): Is ICT mandatory or voluntary at your institution? Table1 shows that the majority of the full-time lecturers (89\%) responded that ICT is mandatory. These participants are in the age bracket of (30-44yrs). The career ranks of these participants are lecturers and they constitute (69\%) of the total academic staff. However, the survey revealed that most of the part-time lecturers ticked the use of ICT as voluntary. Some of these part-time lecturers in the cadre of professors, responded to Q32 as (do not fit my program). Actually in their dispensation, lecturing was done using the chalk board only. Therefore, some of them fill that it is too late to embark on the use of ICT as they are already in the process of pulling out of academic completely.

Research Question (ii): What are the greatest barriers to using ICT to you as an academician? Question Q32 which talk about barriers to use of ICT, have the majority of the respondents (42\%) said that their problem is time; on the other hand (31\%) said that the problem is training. Others respondents (4\%) said that cost are their problem, another group (20\%) said that they need compensation and the final group (3\%) said that, it does not fit their programme. ICT development programme among academic staff of educational institutions especially at the tertiary level is faced by number of obstacles. Prominent among them is the lack of training opportunities for staff. The same problem is recurring in this study again. In a study by (Archibong \& Effiom, 2009), lack of interest, limited access to ICT facilities and lack of training opportunities were among the obstacles to ICT usage among academic staff. (Ijeoma, Joseph, \& Franca, 2010) opined that inadequate ICT facilities, excess workload and funding were identified as major challenges to ICT usage among academic staff in Nigerian universities.

Table 2: Greatest Barrier

\begin{tabular}{llllll}
\hline Variables & Frequency & Percent & Valid Percent & $\begin{array}{c}\text { Cumulative } \\
\text { Percent }\end{array}$ \\
\hline Valid & TIME & 42 & 42.0 & 42.0 & 42.0 \\
& TECHNICAL SUPPORT & 20 & 20.0 & 20.0 & 62.0 \\
& COST & 4 & 4.0 & 4.0 & 66.0 \\
& TRAINING & 31 & 31.0 & 31.0 & 97.0 \\
DOES NOT FIT MY & 3 & 3.0 & 3.0 & 100.0 \\
PROGRAM & 100 & 100.0 & 100.0 & \\
Total & & & & \\
\hline
\end{tabular}

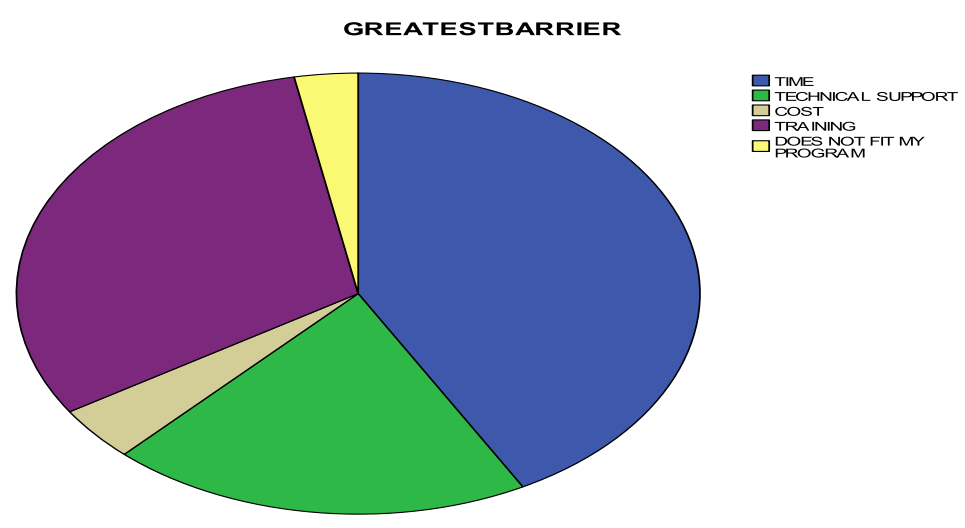

Discussion: The study revealed that although the use of ICT is mandatory in the Nigerian HEIs, there is no incentive and encouragement for the academic staff to enable them to embark on ICT use properly. Inadequate ICT facilities, excess workload, lack of funding and lack of training opportunities, were identified as major challenges to ICT usage among academic staff. Although some HEIs have the zeal to establish effective ICT education programmes, they are faced with the great problems of proper implementation of the programme. The most important of these is poor ICT acceptance and usage among Nigerian higher education 
practitioners. Almost all African countries' basic ICT infrastructures are inadequate; this is due to lack of electricity to power the ICT materials and poor telecommunication facilities. Above all, this lack of access to ICT infrastructure is the result of insufficient funding (Ololube \& Egbezor, 2009).

\section{Conclusion}

The implementation of the use of ICTs in education was and is essential to address the issues of how ICTs is used as object of learning (to acquire ICTs related skills) and as a tool for realizing particular educational objectives, especially the ones that are believed to be associated with the learning society, efficiency, competitiveness, effective learning, print content delivery, and distance education. The basic aim is to provide concrete results about the use of ICTs in education. The finding of this study shows that Nigerian HEIs are lagging behind in the application of ICT to teaching and learning. The inadequacy of the ICT facilities and the lack of opportunities for training staff on how to use ICT for teaching and learning are major problems that must be looked into with an eagle eye. Despite the perceived benefits in the use of ICT in HEIs, many factors are inhibiting its successful application in Nigerian HEIs. Recommendations made were that all employed teachers in Federal, State and Private institutions should undertake mandatory training and retraining on ICT programmes. This is to provide them with practical and functional knowledge of computer, internet and associated areas of ICT for improved effectiveness and efficiency. The government should develop ICT policies and practices that would support lecturers in their academic work and students in their learning. ICT tools should be made more accessible to both academic staff and students.

\section{References}

Achimugu, P., Oluwagbemi, O., Oluwaranti, A. \& Afolabi, B. (2009). Adoption of Information and Communication Technologies in Developing Countries: An Impact Analysis. JITI, 9(1), 37-46.

Archibong, I. A. \& Effiom, D. O. (2009). ICT in University Education: Usage and Challenges among Academic Staff. Africa Research Review, 3(2), 404-414.

Bridget, S. (2008). Factors Affecting Teachers'Pedagogical Adoption of ICT. International Handbook of Information Technology in Primary and Secondary Education, 449-460.

Chiemeke, S. C. \& Longe, O. B. (2007). Information communication Technology in Nigeria: Prospecta, Challenges and Metrics. Asian Journal of Information Technology, 45, 12-19.

DeLacey, B. \& Leonard, D. (2002). Case study on technology and distance in education at the Harvard Business School. Education Technology and Society, 5(2), 2-26.

Dutton, W. H. \& Loader, B. D. (Eds.). (2002). Digital Academe: New Media and Institutions in Higher Education and learning. London: Routledge.

GeSCI. (2007). Global e-schools and communities initiatives: Infrastructure and connectivity. http://www.gesci.org/policy.html.

Ijeoma, A. A., Joseph, E. O. \& Franca, A. (2010). ICT Competence among Academic staff in Unversities in Cross Rivers State, Nigeria. . Computer and Information Science, 3(4), 109-115.

Modupe, O. \& Binuomote, M. O. (2007). Awarenss and Adoption of Infromation and Communication Technology among Secrtarial Staff of Ladoke Akintola University of Technology, Ogbomaso, Nigeria. Social Science, 2, 57-59.

Ololube, N. P. \& Egbezor, D. E. (2009). Educational technology and Flexible education in Nigeria: Meeting the need for effective teacher education. In S. Marshal, W. Kinthia and W. Taylor (Eds), Bridging the Knowledge Divide. Educational technology for develpoment, 391-413.

Oye, N. D., A.Iahad, N. \& Ab.Rahim, N. (2011). Adoption and Acceptance of ICT Innovations in Nigerian Public Universities. International Journal of Computer Science Engineering and Technology, 1(7), 434- 443.

Oye, N. D., Salleh, M. \& Iahad, N. A. (2010). Holistic E-learning in Nigerian Higher Education Institutions. Journal of Computing, 2(11), 20-26.

Radcliffe, D. (2002). Technological and pedagogical convergence work-based and campus-based learning. Educational Technology and Society, 5(2), http://www.ifets.info/journals/5_2/radcliffe.html.

UNESCO. (2009). UNESCO portal on Higher Education Institutions: : Higher Education Institutions in Nigeria. 